\title{
Motivasi Orang Tua Dalam Mendidik Anak Pada Usia Dini Di TK Abu Abdillah Al-Islami Desa Medas Kecamatan Gunungsari Lombok Barat
}

\author{
HUSNAN, AHMAD HELWANI \\ Fakultas Agama Islam Universitas Muhammadiyah Mataram \\ Jl. K.H. Ahmad Dahlan No. I Pagesangan - Mataram \\ Korespondensi Penulis:
}

\begin{abstract}
ABSTRAK
Kata Kunci,motivasi,pendidikan, usia dini, deskriptif, tren kehidupan.

Membekali anak dengan pendidikan adalah hak anak dan kewajiban bagi orang tua. Untuk itu orang tua harus memberikan pendidikan terbaik bagi anak-anak demi masa depan mereka. Orang tua memiliki motivasi besar untuk mendidik anak anak mereka sejak dini, karena itulah banyak disaksikan dimana-mana bahwa anak-anak kini sudah mulai belajar ketika mereke berumur tiga tahun. Jenis penelitian ini adalah kualitatif dengan pendkatan fenomenoligi diskriptif. Data-data yang didapatkan dari penelitian ini adalah gambaran dilapangan terkait fenomena dan semangat para orang tua yang cukup besar dalam memberikan pendidikan untuk anak-anak mereka sejak dini. Data penelitian diperoleh dengan cara observasi, wawancara dan dokumentasi. Motivasi orang tua dalam memberikan pendidikan kepada anak-anak mereka di pengaruhi oleh tiga hal, pertama, para orang tua menginginkan anak menjadi lebih baik dari mereka. Kedua, semaraknya para orang tua yang memberikan pendidikan kepada anak-anak mereka sejak dini., Ketiga mendidik anak sejak dini adalah bagian dari tren kehidupan saat ini.
\end{abstract}

Pendahuluan

Pendidikan adalah unsure utama bagi kemajuan dan kesejahteraan umat manusia. Maju mundurnya pendidikan suatau bangsa tergantung sejauh mana kualitas pendidikan yang dimiliki. Dalam lingkup kecil pendidikan bertujuan untuk membentuk individu menjadi lebih baik, sehingga para peserta didik diharapkan mampu secara mandiri menyelesaikan segala permasalahan yang dihadapi.

Orang tua selalu berharap agar anak keturunan mereka menjadi generasi yang dapat bermanfaat bagi agama, nusa dan bangsa. Secara biologis, hubungan antara orang tua dan anak-anak merupakan hubungan yang bersifat kudrati dan alami. Disebut demikian karena sudah menjadi takdir manusia untuk menjadi orang tua yang memiliki kewajiban dan hak dalam memberikan penghidupan kepada mereka. sedangkan secara psikologis hubungan orang tua dan anak mengedepankan nila-nilai moral sebagai tolak ukur dalam membentuk hubungan yang harmonis dalam kehidupan sehari-hari. Untuk menjaga hubungan tersebut secara primordial agama merupakan pedoman pasti yang harus diamalkan. orang tua menuntut anak-anak mereka secara mutlak untuk mengamalkan nilai-nilai agama dalam kehidupan sehari-hari.

Dalam persefektif Islam, orang tua diharuskan untuk mendidik anaknya agar menjadi seorang muslim sejati sesuai dengan fitrahnya sebagai hamba Allah yang telah mengikat diri dengan janji tauhid untuk menyatakan bahwa Allah adalah Tuhan Yang maha Esa.

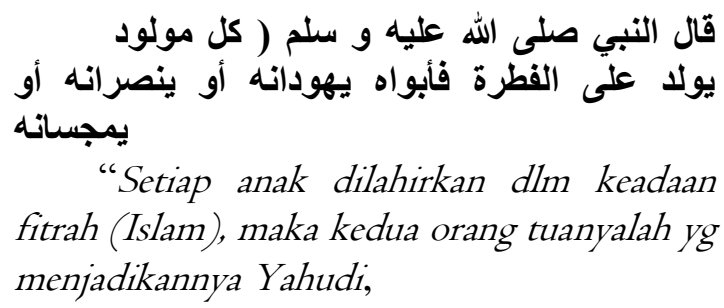

"Setiap anak dilahirkan dlm keadaan fitrah (Islam), maka kedua orang tuanyalah yg menjadikannya Yahudi, 
Nashrani atau Majusi."42

Hadis tersebut menjelaskan tentang bagaimana peran vital orang tua dalam memberikan pendidikan yang terbaik bagi anak-anak mereka agar tetap pada jalan yang suci (Islam). Untuk itulah para orang tua memiliki dorongan kuat berupa motivasi keagamaan dalam menanamkan nilai-nilai agama sejak dini kepada anak mereka sesuai dengan pendidikan dalam Islam.

Syari'at islam tidak akan dihayati dan diamalkan orang apabila hanya diajarkan saja, tetapi harus dididik melalui proses pendidikan. Nabi telah mengajak orang untuk beriman dan beramal serta berakhlak baik sesuai dengan ajaran islam dengan berbagai metode dan pendekatan. Dari satu segi kita melihat bahwa pendidikan islam itu banyak ditujukan kepada perbaikan sikap mental yang akan terwujud dalam perbuatan, baik bagi keperluan diri sendiri, maupun orang lain. Dari segi lainnya, pendidikan islam tidak hanya bersifat teoritis saja, tetapi juga praktis. Ajaran islam tidak memisahkan antara iman dan amal, karena ajaran islam berisi sikap dan tingkah laku pribadi masyarakat menuju kesejahteraan hidup perorangan maupun bersama. Maka pendidikan islam adalah pendidikan individu dan pendidikan masyarakat. Semula orang yang bertugas mendidik adalah para Nabi dan Rasul, selanjutnya para ulama, kemudian kita harus cerdiklah sebagai penerus tugas dan kewajiban mereka.43

Motivasi orang tua yang memberikan pendidikan sejak dini kepada anak-anak mereka adalah hal yang cukup positif. Ini bermakna bahwa kesadaran masyarakat secara umum dan para wali santri secara khusus tentang petingnya pendidikan telah tumbuh. Fenomena ini perlu apresiasi dan dukungan terus menurus dari semua pihak terutama pemerintah untuk menyiapakan segala sesuatunya agara pendidikan untuk anak bangsa dapat merata.

Dianatara lembaga pendidikan yang dilegalkan oleh pemerintah adalah pendidikan anak usia dini, seperti yang tercantum dalam Permendiknas no 58 tahun 2009. Pendidikan

42 Hadis diriwayatkan al-Bukhari\&Muslim dalam sahihnya

43 Zakiah Dradjat. Ilmu pendidikan Islam, Bumi Aksara Jakarta, 2008. hal 34 anak usia dini (PAUD) adalah jenjang pendidikan sebelum jenjang pendidikan dasar yang merupakan suatu upaya pembinaan yang ditujukan bagi anak sejak lahir sampai dengan usia enam tahun yang dilakukan melalui pemberian rangsangan pendidikan untuk membantu pertumbuhan dan perkembangan jasmani dan rohani agar anak memiliki kesiapan dalam memasuki pendidikan lebih lanjut, yang diselenggarakan pada jalur formal, nonformal, dan informal.

Pendidikan anak usia dini merupakan salah satu bentuk penyelenggaraan pendidikan yang menitikberatkan pada peletakan dasar ke arah pertumbuhan dan 5 perkembangan, yaitu : perkembangan moral dan agama, perkembangan fisik (koordinasi motorik halus dan kasar), kecerdasan/kognitif (daya pikir, daya cipta), sosio emosional (sikap dan emosi) bahasa dan komunikasi, sesuai dengan keunikan dan tahap-tahap perkembangan sesuai kelompok usia yang dilalui oleh anak usia dini. Agar lima unsure perkembangan tersebut dapat berkembang baik maka, para orang tua memulai proses pendidikan untuk anak-anak mereka sejak berumur tiga tahun dan seterusnya.

Motiv para orang tua untuk melihat anakanak mereka tumbuh dan berkembang agar menjadi individu cukup besar ditengah masyarakat saat ini. Fenomena tersebut didukung oleh terbentuknya sarana dan prasarana pendidikan untuk anak usia dini di tengah masyarakat. Tidak hanya di setiap desa, bahkan di setiap dusun lembaga pendidikan untuk anak usia dini mudah ditemukan. Saat ini orang tua cukup terbantu dengan adanya lembaga pendidikan tersebut. Karena dengan situasi tersebut para orang tua yang tidak dapat memberikan pendidikan dan pengasuhan maksimal kepada anak-anak mereka dapat diringankan. Ada beberapa factor pendukung alasan para orang tua menyerhkan anak-anak mereka ke lembaga pendidikan sejak dini, yaitu: orang tua tidak cukup mampu memberikan pendidikan maksimal kepada anak-anak mereka, orang tua yang sibuk dengan dunia kerja dan lembaga pendidikan tempat mereka menyerahkan anak-anak mereka dijadikan sebagai tempat bersilaturrahmi dengan para wali murid lainnya. 
Fenomena tersebut perlu dikaji untuk mengetahui factor dominan dibalik motivasi besar para orang tua mendidik anak-anak mereka sejak usia dini. Bukankan pendidikan terbaik untuk anak usia dini adalah pendidikan langsung oleh orang tua. Orang tua adalah madrasah pertama bagi anak-anak dalam memberikan nilai-nilai moral dan membantu tumbuh kembang jasmani mereka. dari ulasan tersebut perlu di ketahui jawaban pasti dari permasalahan tersebut.

Adapun rumusan masalahnya adalah: (I) Motifasi apa yang melatarbelakangi orang tua dalam mendidik anak sejak usia dini? (2) Bagaimana tumbuh kembang anak secara jasmani dan rohani telah mendapatkan pendidikan sejak usia dini?. Secara teoritis penelitian ini diharapkan dapat memberi sejumlah pengetahuan dan informasi tentang motivasi yang melatarbelakangai para wali murid terkait dengan pendidikan usia dini dan perkembangan para peserta didik, dan bermanfaat sebagai bahan kajian atau bahan acuan bagi para pemerhati yang konsen pada pendidikan anak usia dini. Sedangkan secara praktis manfaat penelitian ini Menjadi tambahan informasi bagi pihak-pihak yang terkait langsung dengan pendidikan anak usia dini, bagi penulis dan para peneliti selanjutnya yang ingin melakukan penelitian dalam bidang yang sama., serta Menjadi masukan dan bahan informasi sebagai upaya perbaikan dan pengayaan pengajaran bagi lembaga Pendidikan Anak Usia Dini.

\section{METODE PENELITIAN}

Pendekatan yang peneliti gunakan dalam penelitian ini, adalah pendekatan kualitatif deskriptif, dimana penulis berusaha untuk memahami arti peristiwa dan kaitannya terhadap orang yang berada pada situasi tertentu. Dengan pendekatan ini penulis akan mendeskripsikan segala realitas yang ditemukan di lapangan berupa prilaku, kegiatan, keadaan, status dan fenomena-fenomena yang terjadi pada proses pembelajaran anak usia dini dan bagaimana perkembangan motorik dan kognitif mereka selama proses pembelajaran dilaksanakan. Penelitan ini dilakukan pada lembaga pendidikan anak usia dini $\mathrm{Abu}$
Abdillah. Adapun waktu yang peneliti butuhkan dalam penelitian ini kurang lebih empat bulan (Agustus sampai Oktober 2017). Sumber data dalam penelitian ini adalah: Ketua Yayasan Tk Abu Abdillah, para pengajar dan wali murid. Tehnik pengumpulan data adalah Pertama Observasi diartikan sebagai pengamatan sistematik terhadap gejala yang tampak pada obyek penelitian.Kedua Wawancara, yaitu sebuah dialog atau percakapan yang dilakukan oleh pewawancara (interviewer) untuk memperoleh informasi dari yang diwawancarai (interviewed). Untuk menganalisa data-data yang didapat, penulis menggunakan metode analisis induktif.

\section{Hasil dan Pembahasan}

\section{A. Urgensi Pendidikan sejak Usia Dini dalam Islam}

Dalam konsep Islam pendidikan itu dihukumi wajib dan dimulai sejak masa buaian hingga jasad dimasukkan dalam liang lahad. Kenapa demikian, tentunya disebabkan oleh alasan yang besar dibalik semua itu, bahkan secara aklamasi masyarakat berkeyakinan bahwa hanya dengan pendidikanlah hidup ini dapat meningkat dan berkembang menjadi lebih baik. Sejalan dengan itu, maka pendidikan diartikan sebagai proses pengubahan sikap dan tata laku seseorang atau kelompok orang dalam usaha mendewasakan manusia melalui upaya pengajaran dan pelatihan. ${ }^{44}$ Pendidikan adalah cara satu-satunya yang dapat dilaksanakan untuk dapat membentuk sikap dan prilaku manusia. Manusia sebagai ciptaan Tuhan yang paling sempurna dibekali dengan potensi berupa akal dan hawa nafsu. Bila akal yang mendominasi maka menjadi baiklah dia begitu juga sebaliknya bila hawa nafsu yang merajai. Akal dan hawa nafsu dua komponen penting dalam jiwa setiap manusia, untuk itu ia harus diarahkan dan dikembangkan secara porposional agar berdampak positif bagi pemiliknya.

Pendidikan diyakini dapat membentuk dan mengarahkan keduanya sesuai garis ed

44 Muhibbin Syah, Psikologi Pendidikan Dengan Pendekatan Baru, (Remaja Rosdakarya:Bandung, 2013), hal. I0 
ar masing-masing. Untuk itu, dari awal manusia harus memperoleh pendidikan agar keduanya selaras dan seimbang. Dalam rangka itu orang tua paham betul akan hak dan kewajibannya dalam mengemban amanah yang diberikan berupa putra dan putri oleh Tuhan Yang Maha Kuasa. Ditangan orang tualah baik buruknya prilaku anak-anak ditentukan. Setiap anak terlahir suci, namun kesucian itu dapat saja kotor dan hina tergantung bagaimana orang tua memberikan pendidikan kepada mereka. ${ }^{45}$ Untuk itu orang tua diberikan beban untuk mendidik anak-anaknya agar potensi yang mereka miliki dapat meningkat sebagaimana arti dari pendidikan itu sendiri yakni, to elicite, to give rise to,.

Dalam rangka meningkatkan keperibadian anak, maka para orang tua saat ini berupaya membekali anak-anak mereka dengan memberikan pendidikan sejak dini. Memberikan pendidikan kepada anak sejak dini pada zaman sekarang merupakan fenomena luar biasa, bila melihat perkembangan pertumbuhan institusi pendidikan pada awal tahun dua ribuan. Saat ini sekolah untuk anak usia dini didirikan di setiap desa dan tentu ini sebuah kemajuan bagi masyarakat karena semakin sadar dengan arti penting pendidikan. ${ }^{46}$ Dengan tersedianya sarana dan prasarana pendidikan untuk anak usia dini, maka para ornag tua memiliki kesempatan untuk mendidik anakanak mereka.

Memberikan pendidikan sejak dini dalam Islam memiliki dasar pijakan yang kuat dalam Hadist yang disabdakan oleh Rasulullah SAW. "tuntutlah ilmu dari masa buaian sampai liang lahad" (HR Ibnu Abdul Barr). ${ }^{47}$ Dalam hadis

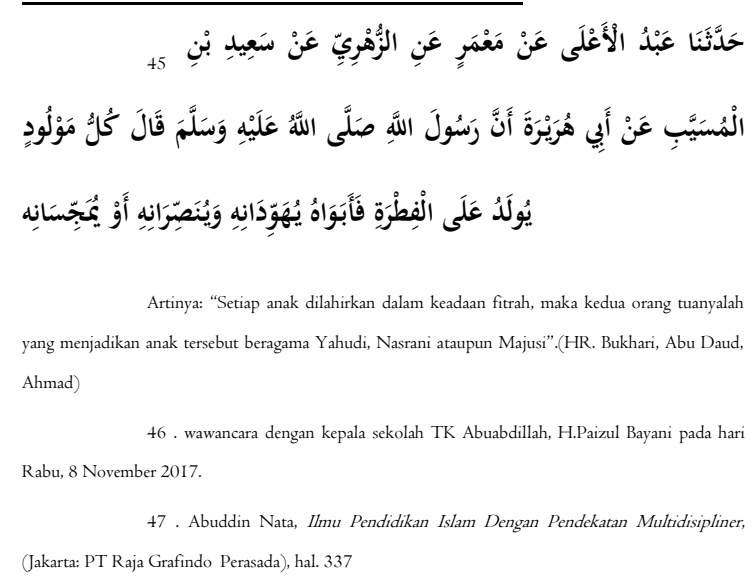

lain Rasulullah juga menyebutkan tentang bagaimana orangtua memberikan tuntunan dalam mendidik anak agar mereka memiliki karakter dan sifat mandiri.

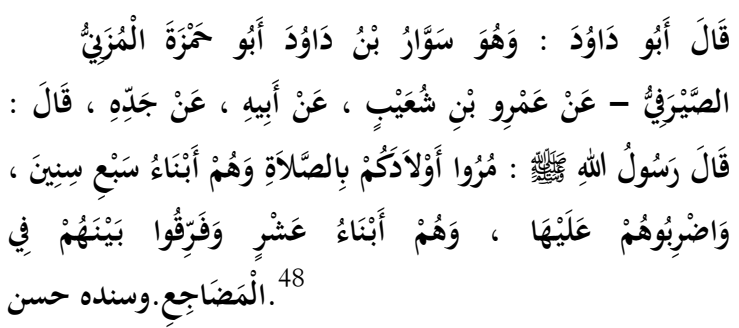

Artinya; perintahkanlah anak-anakmu untuk salat ketika berumur tujuh tahun dan pukullah mereka bila enggan saat berumur sepuluh tahun dan pisahkan mereka dari tempat tidur.

Pada hadis tersebut memerintahkan umat Islam agar memulai sesuatau sejak dini. Begitu pula dengan pendidikan dan pembiasaan kepada anak-anak agar mereka mudah dibentuk. Membentuk sesuatu ketika masih muda lebih mudah daripada membentuk mereka setelah remaja dan dewasa. Maka jelas sekali pendidikan kepada anak-anak penting sekali untuk dimulai dari umur belia seperti yang dianjurkan oleh Rasulullah SAW.

\section{Dini \\ Manfaat Pendidikan Anak Sejak Usia \\ Pendidikan dalam Islam sejatinya dimulai} sejak anak masih dalam buaian sampai ke liang lahat seperti yang disabdakan oleh Baginda Nabi SAW. Dengan demikian pendidikan tidak memiliki batasan kapan harus dimulai. Pendidikan anak usia dini sesungguhnya bertujuan untuk mengembangkan potensi peserta didik menjadi lebih maksimal. Mengacu pada pengertian pendidikana anak usia dini yaitu sebuah proses pembinaan tumbuh berkembangnya anak usia lahir hingga enam tahun secara menyeluruh, yang mencapai aspek fisik-non fisik dengan memberikan ransangan bagi perekembangan jasmanai, rohani (moral dan spiritual), motoric, akal piker, emosional, dan social yang tepat agar anak dapat tumbuh dan berkembang secara optimal.

Dengan demikian dapat dijabarkan bahwa pendidikan anak usia dini memiliki manfaat sebagai; Pertama, pendidikan anak usia dini sebagai wadah untuk menstimulasi, 
membimbing, mengasuh, dan pemberian kegiatan pembelajaran yang akan menghasilakan kemampuan dan keterampilan pada anak. Kedua, pendidikan anak usia dini sebagai bentuk penyelenggaraan yang menitik beratkan pada peletakan dasar kea rah pertumbuhan dan perkembangan fisik (kordinasi motoric halus dan kasar), kecerdasan (dayapikir, daya cipta, kecerdasan emosi, dan kecerdasan spiritual), sosio-emosional (sikap prilaku serta agama), bahasa dan komunikasi. Ketiga, melalui pendidikan anak usia dini, maka pertumbuhan pendidikan anak disesuaikan dengan tahap-tahap perkembangan yang dilalui oleh anak usia dini.

Dilihat dari tiga tujuan utama dari pendidikan anak di usia dini seperti yang telah disebutkan, maka jelas bahwa ketiga hal tersebut juga menjadi acuan dan tujuan pendidikan di TK Abuadillah Al-Islami Medas. Para peserta didik di TK Abuabdillah diberikan bimbingan berupa pembelajaran agar peserta didik memiliki kemampuan dan keterampilan. Pembelajaran dimulai pukul 08.00 sampai dengan pukul 10.30 untuk hari senin sampai hari kamis sedangkan hari jumaat pembelajaran dimulai pukul 08.00 sampai dengan 10.00. Pembelajaran di TK Abu Abdillah menitk beratkan pada bimbingan agar peserta didik mampu mengembangkan fisik (kordinasi motoric halus dan kasar), kecerdasan (dayapikir, daya cipta, kecerdasan emosi, dan kecerdasan spiritual), sosio-emosional (sikap prilaku serta agama), bahasa dan komunikasi. ${ }^{49}$

Dengan demikian bahwa pendidikan awal yang diberikan pada anak usia dini sangant bermanfaat untuk mengembangkan fisik dan mental para peserta didik. Pendidikan sejak dini juga merupakan persiapan bagi anak-anak pra sekolah dasar. Diharapkan kemampuan membaca menulis dan menghitung sudah tercapai sebelum mereka masuk di sekolah dasar. Kemampuan menulis, membaca dan menghitung telah dikembangkan di TK Abuabdillah, jadi setiap peserta didik yang telah menghakiri pendidikan taman kanak-kanak benar benar telah memiliki tiga kemampuan tersebut.

49 observasi pada proses pembelajaran di TK Abuabdillah pada tanggal 9 November
Motifasi Orang Tua Dalam Mendidik Anak sejak Usia Dini

Seperti yang banyak disebutkan oleh para Ahli bahwa motivasi sesungguhnya adalah dorongan yang muncul dalam diri seseorang untuk melakukan sesuatu karena adanya sesuatu yang mempengaruhinya. Motivasi adalah sesuatu keadaan yang membutuhkan ransangan untuk dapat bergerak dan berkembang. Timbulnya motivasi berawal dari suatu rangkaian interaksi antar berbagai factor meliputi Individu dengan segala unsurunsurnya : kemampuan dan ketrampilan, kebiasaan, sikap dan sistem nilai yang dianut, pengalaman traumatis, latar belakang kehidupan sosial budaya, tingkat kedewasaan.

Melihat berbagai factor yang menyebabkan munculnya motifasi terhadap seseorang, maka factor tersebut juga cukup kuat mempengaruhi motif orang tua dalam memberikan pendidikan kepada putra putri mereka. Orang tua memiliki harapan besar terhadap anak anak mereka agar menjadi generasi yang bermanfaat bagi semua orang. Demi harapan tersebut maka, para orang tua memberikan pendidikan yang terbaik kepada anak anak mereka. Para wali murid di TK Abuabdillah Al-Islami Medas juga memiliki harapan serupa.

Berdasar pada wawancara yang dilakukan bersama beberapa wali murid ${ }^{50}$ motifasi yang mendasari mereka untuk memberikan pendidikan sejak dini kepada anak anak mereka dapat dibagi menjadi dua, yaitu motif belajar dan motif silaturrahmi. Motif belajar adalah dorongan yang hadir dari para wali murid untuk memberikan pendidikan dan pembelajaran kepada anak anak mereka dengan cara menyekolahkan mereka di TK Abuabdillah Al-Islami agar mereka dapat tumbuh dan berkembang dengan baik.

Motif belajar ini sesungguhnya dilatarbelakngi oleh maraknya pendidikan anak usia dini yang didirikan oleh para Pendidik diberbagai tempat. Karena tersedianya berbagai fasilitas yang ditawarkan sehingga masyarakat saat ini ramai ramai menyerahkan pendidikan putra putri mereka di PAUD dan

50 Wawancara dilakukan bersama ibu hijazi, ibu hafiz, dan ibu Hj. Syarifah pada tanggal 23 Desember 2017 di TK Abuabdillah Al-Islami Medas Kec. Gunungsari. 
TK. Masyarakat pun satu dengan yang lainnya saling mempengaruhi untuk memsukkan putra putri mereka. Selaras dengan fakta tersebut, motivasi sebagai proses batin atau proses psikologis dalam diri seseorang,sesungguhnya memiliki factor-faktor pencetus yang dapat menggerakkannya dan di kelompokkan menjadi factor eksternal dan factor internal. ${ }^{51}$ :

\section{Faktor Ekstern}

Lingkungan kerja

Pemimpin dan kepemimpinannya

Tuntutan perkembangan organisasi atau tugas

Dorongan atau bimbingan atasan

\section{Faktor Intern}

Pembawaan individu

Tingkat pendidikan

Pengalaman masa lampau

Keinginan atau harapan masa depan.

Berangkat dari dua factor tersebut maka yang menjadi lokomotif para wali santri untuk menyerahkan pendidikan anak anak mereka di TK Abuabdillah Medas Gunungsari dipengaruhi oleh factor lingkungan, pengalaman masa lampau dan harapan masa depan. Alasan tersebut diperkuat oleh para wali santri yang menyatakan, bahwa maraknya para warga masyarakat yang menyekolahkan anak sejak dini baik di PAUD dan TK menjadi dasar motifasi para orang tua dan yang terpenting para wali murid ingin kehidupan anak anak mereka menjadi lebih baik dari mereka. $^{52}$

\section{Membentuk Karakter}

Istilah pendidikan karakter mulai muncul pada akhir-akhir ini setelah terjadi degradasi moral di tengah masyarakat dan anak bangsa. Karakter merupakan kumpulan nilai-nilai baik yang menjadi landasan atau pedoman sikap dan perilaku seseorang. Karakter memiliki nilai-nilai atau virtues karakter yang dianggap baik atau buruk secara universal. Untuk menumbuhkan

5I Dougles Brown, Prinsip Pembelajaran dan Pengajaran Bahasa, (Pearon Education: Jakarta), Hal. 185

52 wawancara dengan ibu rehan pada tanggal 23 Desember 2017 di TK Abuabdillah Al-Islami Medas Kec. Gunungsari karakter yang baik ini diperlukan pendidikan karakter.

Secara etimologis istilah karakter berasal dari bahasa Yunani yaitu,karaso yang berarti cetak biru, format dasar, dan sidik seperti dalam sidik jari. Dalam hal ini karakter diartikan sebagai sesuatu yang tidak dapat dikuasai oleh intervensi manusiawi, seperti ganasnya laut dengan gelombang pasang dan angin yang menyertainya. ${ }^{53}$ Orang yang memiliki karakter kuat adalah mereka yang tidak mau dukuasai oleh sekumpulan realitas yang telah ada dan begitu saja. Menurut kamus besar bahasa Indonesia karakter diartikan sebagai watak, tabiat, pembawaan, dan kebiasaan. ${ }^{54}$ Pengertian ini sejalan dengan uraian pusat bahasa Depdiknas yang mengartikan karakter sebagai bawaan, hati, jiwa, keperibadian, budi pekerti, perilaku, personalitas, sifat, tabiat.

Karakter tidak bisa tumbuh dan berkembang begitu saja tanpa adanya kesengajaan yang pasti untuk mengembangkannya. Untuk itu dibutuhkan pelatihan dan bimbingan agar potensi bawaan berupa fitrah itu sejalan dengan petunjuk petunjuk agama. Pendidikan sebagai wadah pembelajaran dan pelatihan sudah menyediakan kesempatan untuk pengembangan itu.

Taman Kanak-kanak Abuabdillah AlIslami Medas Kecamatan Gunungsari sejatinya cukup menekankan pembelajaran karakter kepada peserta didiknya. Hal tersebut dapat dilihat dari berbagai kegitan yang dilaksanakan setiap harinya ketika peserta didik hadir di TK Abuabdillah. Diantara bentuk pelatihan yang dibiasakan kepada peserta didik adalah:

Mengucapkan salam dan bersalaman

Mebaca doa dalam setiap kegiatan

Solidaritas dan persaudaraan

Bersemangat dan sehat

Bertanggungjawab

Perkembangan fisik dan psikologis anak didik Pada Pendidikan Anak Usia Dini

53 Doni Keosoema, Pendidikan Karakter; Strategi Mendidik Anak di Zaman Global (Grasindo: Jakarta, 20I I), hal. 90

54 Pius A. Partanto dan Dahlan Al-Barry, Kamus Ilmiah Populer, (Surabaya: Arkola, 
Tujuan dari pembelajaran adalah bagaimana membentuk dan mengembangkan fisik dan psikis peserta didik menjadi lebih baik. Pendidikan anak pada usia dini sejatinya adalah memberikan bimbingan kepada anak agar fisik dan psikologi mereka menjadi matang. Ada tiga domain utama yang harus dikembangkan dalam proses pembelajaran anak usia dini, yaitu: perkembangan motor (fisik), perkembangan kognitif, dan perkembangan social dan moral.

Perkembangan fisik dilaksankan dengan melatih para peserta didik agar mereka matang dalam memfungsikan motoric mereka. Di TK Abuabdillah letihan motorik ini dilakukan dengan cara mengerjakan latihan latihan. Setiap peserta didik di TK Abuabdillah diberikan buku latihan. Menurut peneliti ada dua motoric yang utama dilatih yaitu, mata, telinga dan tangan. Mata di latih untuk dapat mengidentifikasi huruf yang terputus-putus sehingga mereka benar-benar dapat mengidentifikasi jenis huruf yang mereka lihat. Selanjutnya mereka akan menyambung hurufhuruf tersebut dengan mengikuti garis putusputus yang ada dalam buku latuhan, sehingga mereka dapat membentuk huruf yang sempurna. Kendala yg dihadapi para peserta didik diantranya adalah posisi tangan yang tidak tepat dalam memegang alat tulis, sehingga latihan pertama yang dilakukan adalah bagaimana memegang pensil dengan benar. Semua kapasitas motoric yang dibawa oleh setiap anak sejak lahir akan terus berproses menjadi lebih matang apalagi dibarengi dengan pendidikan dan pengajaran di sekolah yang menjadi pendukung perkembangan motoricfisik anak dalam memperoleh kecakapan ranah karsa dari peserta didik tersebut. ${ }^{55}$

Untuk mematangkan fisik para peserta didik di TK Abuabdillah, para peserta didi juga diberikan latihan fisik berupa olah raga. Para peserta didik di TK Abuadillah diberikan latihan fisik berupa senam dan latihan karate pada setiap hari Sabtu. Orientasi yang dibutuhkan peserta didik pada saat seperti ini dalam olah raga adalah kegembiraan. Oleh karena itu para guru dan pelatih tidak menekankan pada penguasaan teknik. Olah raga perlu diberikan sebagai langkah awal untuk mempersiapkan mental untuk menghadapi berbagai tantangan pada masa yang akan datang. ${ }^{56}$

Perkembangan kognitif merupakan merupakan ranah psikologis manusia yang meliputi setiap prilaku mental yang berhubungan dengan pemahaman, pertimbangan pengolahan informasi, pemecahan masalah, kesengajaan dan keyakinan. Kognitif merupakan ranah kejiwaan yang terpusat pada otak manusia yang berhubungan erat dengan konasi (kehendak) dan afeksi (perasaan) yang bertalian dengan ranah rasa ${ }^{57}$

Ranah kognitif mulai berkembang pada seorang anak mulai dari umur 0-2 tahun. Perkembangan kognitif pada manusia secara umum berproses melalui empat tahap yaitu:

a. Tahap sensory-motor yakni perkembangan ranah kognitif yang terjadi pada usia $0-2$ tahun.

b. Tahap pre-operational, yakni perkembangan ranah kognitif yang terjadi pada 2-7 tahun.

c. Tahap concrete-operational, terjadi pada 7-I I tahun

d. Tahap formal-operational perkembangan kognitif pada usia II-I5 tahun.

Menurut Piaget setiap perkembangan dari kognitif memiliki objek tersendiri dan memiliki istilah-istilah tersendiri.

Sensory-motor schema (skema sensorimotor) serangkaian perilaku terbuka yang tersusun sistematis untuk merespon lingkungan (barang,orang, keadaan, kejadian).

Cognitive schema (skema kognitif) berfungsi untuk memahami hal yang tersirat atau menyimpulkan lingkungan yang direspon.

Object permanence (ketetapan benda) sebuah benda akan tetap ada walaupun tidak dilihat lagi.

Assimilation (asimilasi) proses aktif untuk menggunakan skema dalam merespon lingkungan. 
Accommodation

(akomudasi) penyesuaianaplikasi skema yang cocok dengan lingkungan yang direspon

Equilibirium (ekuilibirium) keseimbngan antara sekema yang digunakan dengan lingkungan yang direspon sebagai hasil ketetapan akomudasi.

Dari sekian istilah dalam kerja kognitif, maka unsur utama untuk dikembangkan dan dibimbing di TK Abuabdillah adalah skemasensori-motor. Hal tersebut sesuai dengan umur para peserta didik, dimana pada tahap ini mereka sedang dibimbing untuk mengembangkan kognitif untuk merespon barang, orang, keadaan dan kejadian. Pada buku latihan para peserta didik dapat dilihat bahwa contain dari buku tersebut memang memperkenal jumlah atau angka dalam bentuk barang dan benda, gambar-gambar tentang cuaca

\section{simpulan}

Dari seluruh ulasan yang telah dipaparkan dalam bab-bab sebelumnya, maka dapat disimpulkan sebagai berikut:

Orang tua memiliki motivasi tinggi untuk memberikan pendidikan kepada anak-anak mereka disebabkan oleh pengaruh lingkungan, dimana pendidikan usia dini saat ini memang sangat popular di tengah masyarakat. Selain itu factor latar belakang orang tua yang memang menginginkan anak-anak mereka yang harus lebih baik dari mereka sendiri, sehingga pada masa yang akan datang anak-anak akan mampu bersaing dan menyelesaikan permasalahanpermasalahan mereka.

Taman kanak-kanak Abuabdillah AlIslami sangat membantu peserta didik dalam mengembangkan kecakapan fisik dan mental mereka. Secara fisik dan mental para peserta didik sudah terbentuk dalam diri mereka berupa kemampuan menulis, menghitung dan membca. Selain itu kemampuan yang bersifat reliji juga dapat mereka peroleh berupa hafalanhafalan ayat pendek dan doa-doa.

\section{Referensi}

Doni Keosoema, Pendidikan Karakter; Strategi Mendidik Anak di Zaman Global Grasindo: Jakarta, 20I I
H. Douglas Brown, Prinsip-Prinsip Pembelajaran dan Pengajaran Bahasa, Jakarta: Pearson Education

Omar Hamalik, Proses Belaj Mengajar, Bumi Aksara: Jakarta, 2009.

Muhibbin Syah, Psikologi Pendidikan, Rosdakarya: Bandung, 2013.

Pius A. Partanto dan Dahlan Al-Barry, Kamus Ilmiah Populer, Surabaya: Arkola, 1994.

Zakiah Dradjat. Ilmu pendidikan Islam, Bumi Aksara Jakarta, 2008.

Zubaidi, Desain Pendidikan Karakter, Konsep dan Aplikasinya dalam Lembaga Pendidikan, Jakarta:Kencana, $201 \mathrm{I}$.

Sahlan Syafei. 2002. Bagaimana Anda Mendidik Anak. Depok: Ghalia Indonesia. Suwarno. 1982. Pengantar Umum Pendidikan. Jakarta: Aksara Baru. Team BPK FKIP UNS. 1985. Dasar Kependidikan. Surakarta: UNS Press. Gaibi. 1937. Motivasi Dalam Kajian. Jakarta: Bumi Persada.

Hamidi, Sadrianto. 20II. Partisipasi Kepemimpinan Organisasi. Bandung: Purnama Mas.

Hasiah. 2006. Tumbuh Kembang Anak Sebagai Individu. Jakarta: Purna Kencana.

Arief Furchan, Pengantar Metode Penulisan Kualitatif, Surabaya:Usaha Nasional, 1992. 